\title{
Effect of Pine oil blended with Methanol on Performance and Emissions in a Diesel Engine
}

\author{
Dr. Hiregoudar Yerrennagoudaru ${ }^{1}$, Manjunatha $\mathrm{K}^{2}$, Sharath Babu ${ }^{3}$ \\ ${ }^{I}$ (Mechanical Engg. Department, RYMEC/VTU, INDIA) \\ ${ }^{2}$ (Mechanical Engg. Department, RYMEC/VTU, INDIA) \\ ${ }^{3}$ (Mechanical Engg. Department, RYMEC/VTU, INDIA)
}

\begin{abstract}
The present fossil fuel crisis and increasing vehicle population made us to think of alternate fuels. The abundance of the fossil fuels is expected to be exhaust in another 30-40 years. The cost of the fossil fuels is day by day increasing and also the emission from these fuels increases the air pollution. With keeping in view of all the above said points, it is made us to think of alternate fuels for all CI Engines. Among alternate fuels, the Pine oil blended with Methanol will promise for substituting the diesel. With pure vegetable oils there is combustion problems and which leads to more emissions in the exhaust. The present investigation evaluates Pine oil blended with Methanol in Diesel Engine. A Twin cylinder Diesel Engine adapted to study the Brake thermal efficiency, Brake specific energy consumption, and emissions in Low Cetane fuels. In this study, the diesel engine was tested using Diesel and Low Cetane Fuels. From this study the emissions like HC and CO has been reduced and Low Cetane Fuels are substitute to diesel fuel. To overcome the above problems we use combustion additives at the time of combustion. So here we use Pine oil blended with Methanol as alternative fuels in diesel Engine and perform various tests and evaluate its performance.
\end{abstract}

Keywords: Diesel, Performance, Emissions, Biofuel, Pine oil

\section{Introduction}

Rising petroleum prices, increasing threat to the environment from vehicle exhaust emissions and fastly depleting stock of fossil fuels have generated an intense international interest in developing alternative renewable fuels for IC engines. Bio fuel is an oxygenated fuel which increases the combustion and makes reduce exhaust emission. It can be produced from crops with high sugar or starch content. Some of these crops include sugarcane, sorghum, corn, barley, cassava, linseedplants, sugar beets etc. Besides being a biomass based renewable fuel, Biofuel has cleaner burning and higher octane rating than the various vegetable oils [1-5]. Jason and Marc (2002) presented the exegetic environmental assessment of lifecycle emissions from M-85, E-85 (used for the gasoline engine) and other alternative fuels [6]. Diesel exhaust is a major contributor to various types of air pollution, including particulate matter (PM), oxides of nitrogen (NOx), and carbon monoxide (CO) [7]. It has been demonstrated that the formation of these air pollutants can be significantly reduced by incorporating or blending oxygenates into the fossil fuels matrix [8]. Diesel engines are an important part of the public and private transportation sector and their use will continue and grow into the future. But their smoke has become biggest threat to health and environment [9]. Keeping in mind the higher octane number of the ethanol, variable compression ratio engine is a good option in this direction using the ethanol diesel blend as fuel; Shaik et al. (2007) demonstrated VCR engine has great potential for improving part-load thermal efficiency and reducing greenhouse gas emissions [10].There were many attempts made to use Biofuel in compression ignition (CI) engine. Huang et al. (2008) carried out tests to study the performance and emissions of the engine fuelled with the ethanol diesel blends [11]. They found it feasible and applicable for the blends with n-butanol to replace pure diesel as the fuel for diesel engine. Bhattacharya and Mishra (2002) evaluated the feasibility of preparing diesel-ethanol blends using $200^{\circ}$ (anhydrous ethanol) and ethanol lower proof [12]. They found that ethanol blends indicated power producing capability of the engine similar to that of diesel. Hansen et al. (2001) found that the properties of ethanol-diesel blends have a significant effect on safety, engine performance, durability and emissions [13]. Wang et al. (2003) analyzed that the most noteworthy benefits of E-diesel use lie with petroleum fuel reductions and reductions in urban $\mathrm{PM}_{10}$ and $\mathrm{CO}$ emissions by heavy vehicle operations [11]. Ajav and Akingbehin (2002) experimentally determined some fuel properties of local ethanol blended with diesel to establish their suitability for use in compression ignition engines [14]. Eckland et al. (1984) presented, State-of-the-Art Report on the Use of Alcohols in Diesel Engines [15]. Techniques that have been evaluated for concurrent use of diesel and alcohols in a compression-ignition engine include (1) alcohol fumigation, (2) dual injection (3) alcohol/diesel fuel emulsions, and (4) alcohol/diesel fuel solutions. Heisey and Lestz (1981) reported significant reductions in particulate generation; however, NOx generation increases [16]. Likos et al. (1982) reported increased NOx and hydrocarbon emissions for diesel-ethanol emulsions [17]. Khan and Gollahalli (1981) reported decreased NOx and hydrocarbon emissions with increased particulate emissions for 
diesel-ethanol emulsions [18]. Lawson et al. (1981) reported increased NOx and decreased particulate emissions with diesel methanol emulsions [19]. Performance and Emission Characteristics of Twin Cylinder CI Engine Using Cottonseed Oil Blended With Methanol [20]. Ahmed (2001) found Diesel engines are major contributors of various types of air polluting exhaust gasses such as particulate matter (PM), carbon monoxide (CO), oxides of nitrogen (NOx), sulfur, and other harmful compounds [21]. Experimental Investigation of Twin Cylinder Diesel Engine Using Linseed oil blend with Ethanol [22].Raoet al. (2008) carried out experiment in order to found out optimum compression ratio, experiments were carried out on a single cylinder four stroke variable compression ratio diesel engine [23]. Experimental Investigation of Twin Cylinder Diesel Engine Using Diesel \& Methanol [24] Investigation of Methanol in Twin cylinder in line 4 Stroke liquid cooled Diesel Engine [25] Investigation of Alternative fuels in Diesel Engine [26-37] T. Le Anh,I.K. Reksowardojo,K. Wattanavichien (1) This chapter summarises findings on the use of biofuels in conventional diesel engines [38] Seung Hyun Yoon, Chang Sik Lee (2) This study was performed to investigate the effect of biogas-biodiesel fuel combustion on the emissions reduction and nanoparticle characteristics in a direct injection (DI) diesel engine[39] F.J. Salvador,J. Martínez-Lopez ,J.-V. Romero ,M.-D. Rosello (3) In this paper, the behavior of the internal nozzle flow of a standard diesel fuel has been compared against a biodiesel fuel (soybean oil) at cavitating and non-cavitating conditions, using a homogeneous equilibrium model[40]

\section{Experimental Setup}

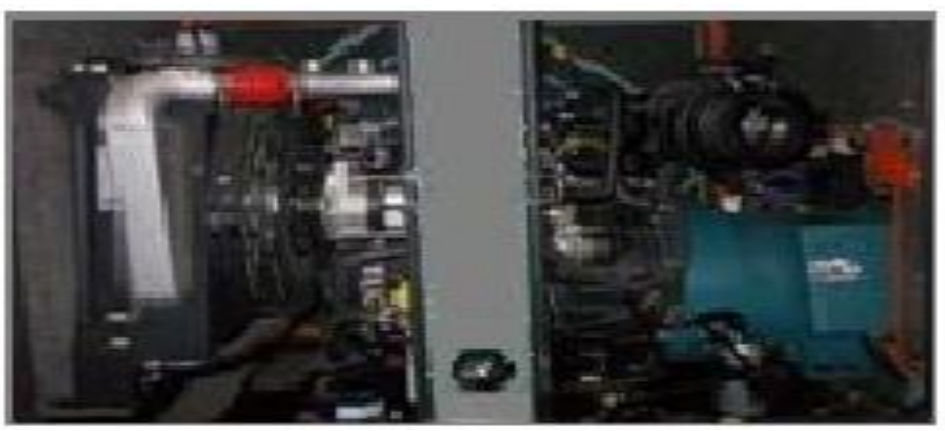

Fig 1: Test engine (Twin cylinder Diesel Engine)

Objective of the present study is to:

\section{Objective}

$>$ It is proposed to use Pine oil blended with Methanol in the diesel engine.

$>$ The emissions like $\mathrm{HC}, \mathrm{CO}_{2}, \mathrm{NOx}$, and Smoke in the exhaust gases are proposed to reduce during the combustion itself.

$>$ To study the performance evaluation of the using Bio fuel blended with Methanol in the diesel engine.

$>$ To analyse the exhaust emissions and measurement, reduction in the exhaust gas.

\section{Properties of Biofuel blended with Alcohol}

\begin{tabular}{|c|c|c|}
\multicolumn{3}{|c}{ Table-1 } \\
\hline Sl.No & Fuel & CV KJ/Kg \\
\hline 1. & Diesel & 44,800 \\
\hline 2. & Pine oil blended with Methanol & 33,222 \\
\hline
\end{tabular}

V. Engine Specification

Table-2

\begin{tabular}{|c|c|}
\hline \multicolumn{2}{|c|}{ Test Engine specification } \\
\hline Injection Pressure & 1800 bar \\
\hline Engine type & Four stroke Twin cylinder diesel engine \\
\hline No. of cylinders & 02 \\
\hline Stroke & $100 \mathrm{~mm}$ \\
\hline Bore Diameter & $87 \mathrm{~mm}$ \\
\hline Engine Power & $15 \mathrm{KVA}$ \\
\hline Compression ratio & $17.5: 1$ \\
\hline RPM & 1500 \\
\hline
\end{tabular}


1. Performance Graphs

\section{Results}

\subsection{Brake Specific Energy Consumption}

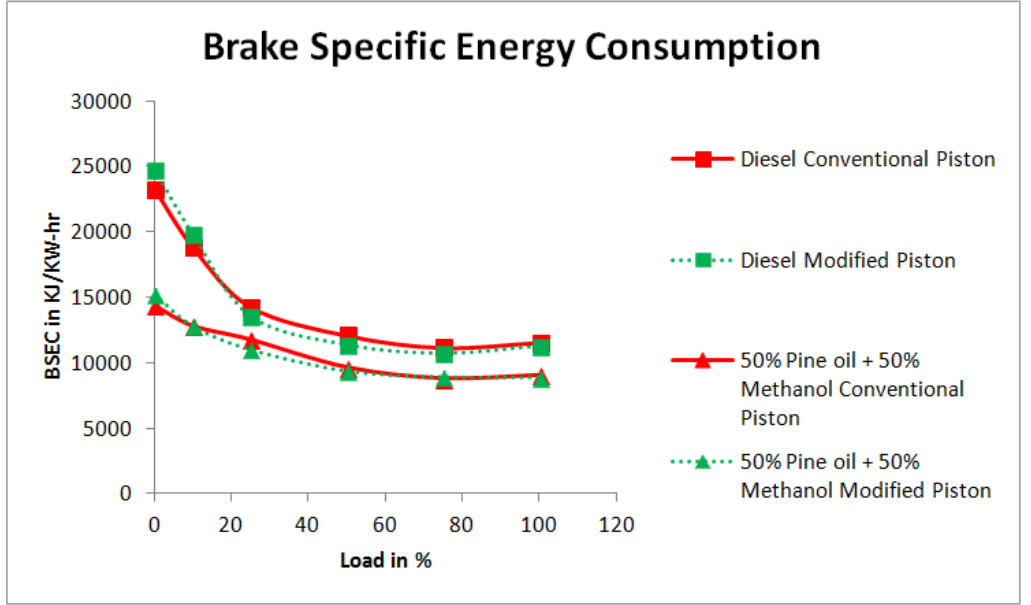

Fig-2 shows the variations of Brake Specific Energy Consumption for Diesel and Pine oil blended with Methanol at Zero Load and Full Load

\subsection{Brake Thermal Efficiency}

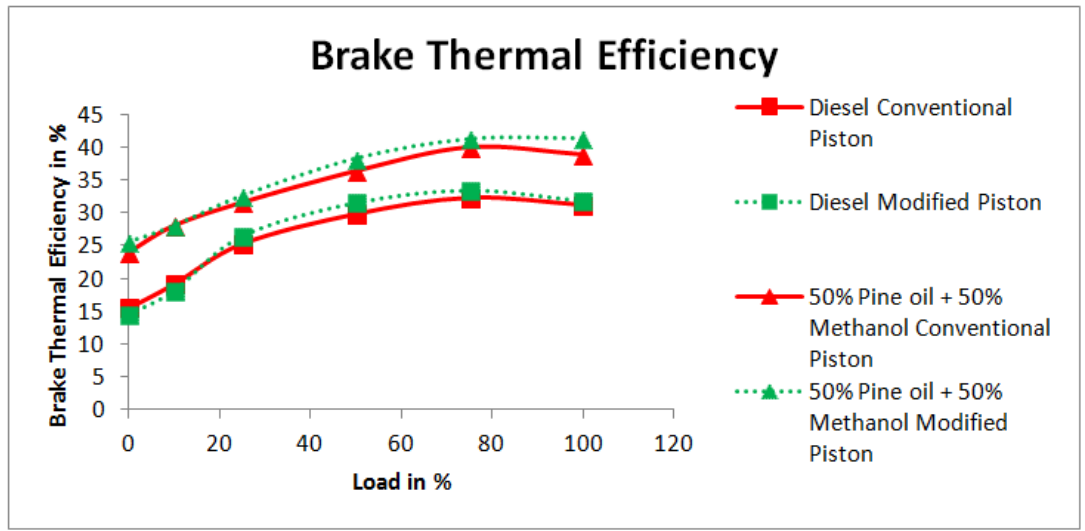

Fig-3 shows the variations of Brake Thermal Efficiency for Diesel and Pine oil blended with Methanol at different Loads

\section{EMISSION Graphs}

\subsection{Unburnt Hydro Carbon}

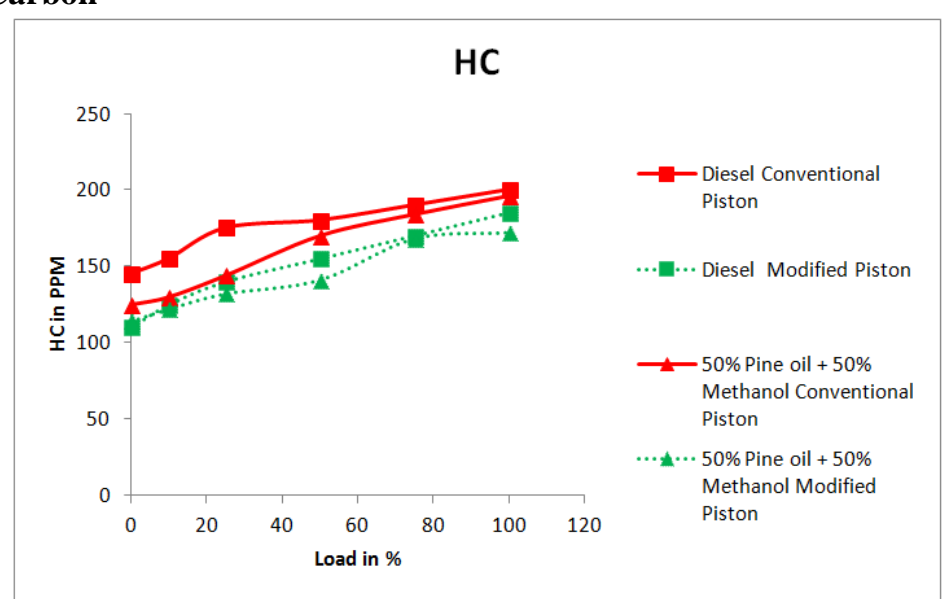

Fig-4 shows the variations of Unburnt Hydro Carbon for Diesel and Pine oil blended with Methanol at Zero Load and Full Load 


\subsection{Carbon Dioxide}

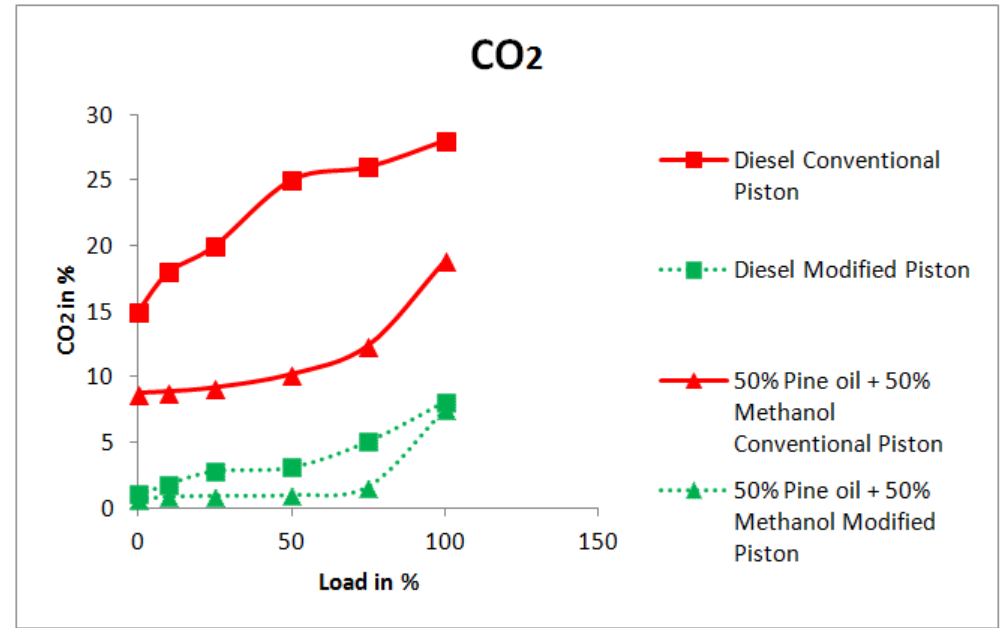

Fig-5 shows the variations of Carbon dioxide for Diesel and Pine oil blended with Methanol at Zero Load and Full Load

\subsection{Nitrogen Dioxide}

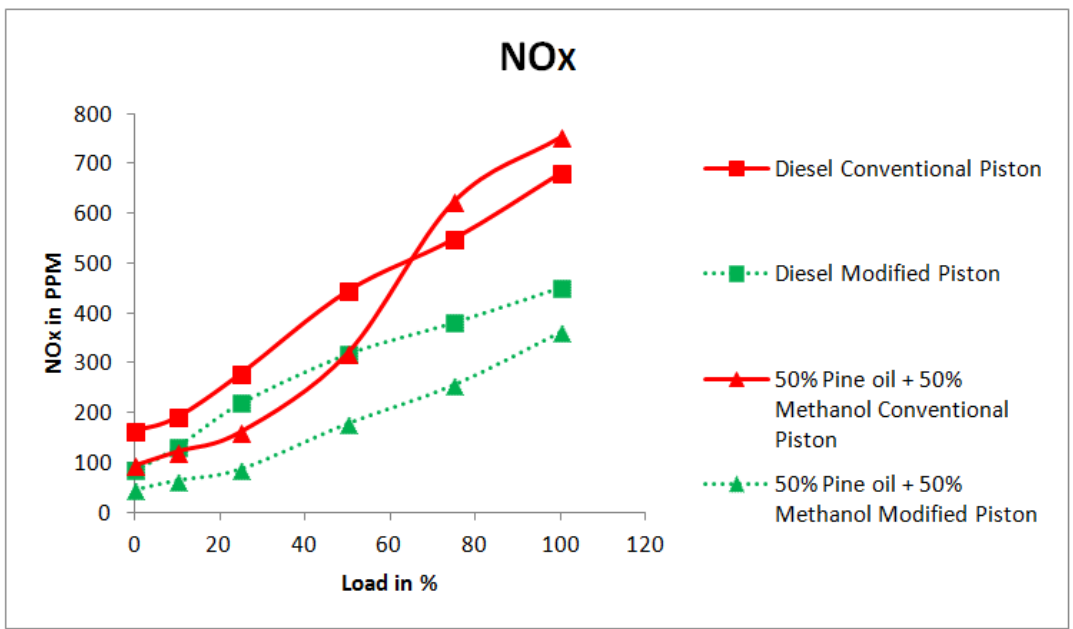

Fig-6 shows the variations of Nitrogen dioxide for Diesel and Pine oil blended with Methanol at Zero Load and Full Load

\subsection{Smoke}

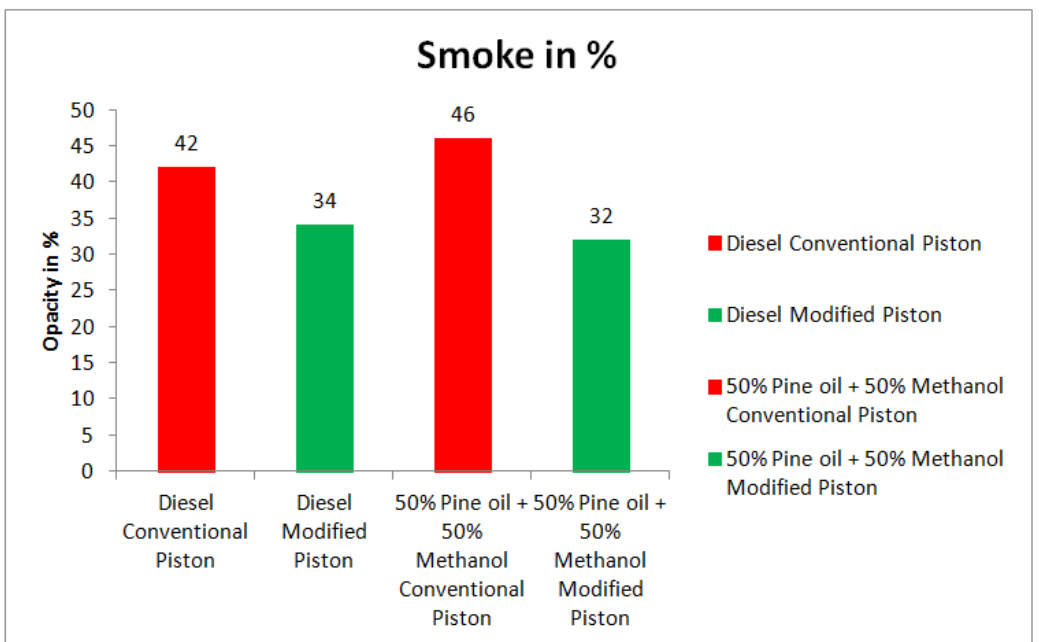

Fig-7 shows the variations of Smoke for Diesel and Pine oil blended with Methanol at Zero Load and Full Load 


\section{Conclusion}

Based on the performance and emissions of Pine oil blended with Methanol, it is concluded that the Pine oil blended with Methanol represents a good alternative fuel with closer performance and better emission characteristics to that of a twin cylinder diesel fuel engine. From the above analysis the Pine oil blended with Methanol shows better performance compared to the Diesel in the sense of better performance characteristics like Brake thermal efficiency, Specific fuel consumption and decrease in the emission parameters like HC, $\mathrm{CO}_{2, \mathrm{NOx}}$,Smoke in Modified Piston compared to Conventional Piston.

\section{References}

[1]. Alan C. Hansen, Qin Zhang and Peter W. L. Lyne, "Ethanol-diesel fuel blends a review", Bioresource Technology, Volume 96, Issue 3, February 2005, Pages 277-285.

[2]. Dr.HiregoudarYerrennagoudar, Manjunatha K, et.al. "Performance \& emission of Twin Cylinder Diesel Engine Using Ethanol”International Journal of Engineering Science and innovative Technology (IJESIT),(ISSN 2319 - 5967) (Online)) Volume No.3, Issue No.4, July2014)

[3]. NevenVoca,BorisVarga,TajanaKricka, DuskaCuric, VanjaJurisic and Ana Matin, "Progress in ethanol production from corn kernel by applying cooking pre-treatment" BioresourceTechnologyVolume 100, Issue 10, May 2009, Pages 2712-2718.

[4]. Avinash Kumar Agarwal, "Biofuels (alcohols and biodiesel) applications as fuels for internal combustion engines" Renewable Energy, 27 November 2006.

[5]. Hakan, Bayraktar."Experimental and theoretical investigation of using gasoline-ethanol blends in spark-ignition engines", Renewable Energy,2005; Volume 30, Issue 11:pp1733-1747.

[6]. Jason J, Daniel Marc, Rosen A, "Exergetic Environmental Assessment of Life Cycle Emissions for various Automobiles and Fuels, Exergy 2 (2002) 283-294

[7]. HwanamKima, Byungchul Choi, "Effect of ethanol-diesel blend fuels on emission and particle size distribution in a common-rail direct injection diesel engine with warm-up catalytic converter", Renewable Energy 33 (2008) 2222-2228.

[8]. De-gang Li, Huang Zhen, Lu Xingcai, Zhang Wu-gao and Yang Jian-guang, "Physico-chemical properties of ethanol-diesel blend fuel and its effect on performance and emissions of diesel engines", Renewable Energy 30 (2005) 967-976.

[9]. SehmusAltuna, HusamettinBulutb and CengizOner, "The comparison of engine performance and exhaust emission characteristics of sesame oil-diesel fuel mixture with diesel fuel in a direct injection diesel engine", Renewable Energy 33 (2008) 1791-1795.

[10]. AmjadShaik, N ShenbagaVinayagaMoorthi, and R Rudramoorthy, "Variable compression ratio engine: a future power plant for automobiles an overview,"Proc. MechE Vol. 221 Part D April 2007. DOI: 10.1243/09544070JAUTO573.

[11]. Jincheng Huang, Yaodong Wang, Shuangding Li, Anthony P. Roskilly,Hongdong Yu, Huifen Li, "Experimental Investigation on the Performance and Emissions of a Diesel Engine Fuelled with Ethanol-diesel Blend,"ATE 2697, 2008.

[12]. T K Bhattacharya and T N Mishra, "Studies on Feasibility of using Lower Proof Ethanol-diesel Blends as Fuel for Compression Ignition Engines",IE (I) Journal-AG 263 145, December 21, 2002.

[13]. Alan C. Hansen, Peter W. L. Lyne, Qin Zhang, "Ethanol-Diesel Blends: A Step towards A Bio-Based Fuel for Diesel Engines", American Society of Agricultural and Biological Engineers (ASAE) August 1, 2001Ajav, E. A. and O. A. Akingbehin, "A Study of someFuel Properties of Local Ethanol Blended with Diesel Fuel”, Journal of Scientific Research and Development .

[14]. R.Kamo And W. Bryzik“ Tacom/Cummins Adiabatic Engine Programm” Sae Paper No. 830314.

[15]. P.Ram Mohan, K.Ram Mohan, C.M. Varaprasad “ Matching Of Injection Timing In L.H.R Engines For Fuel Economy” Proc Of 3rd Asian Pacific International Symposis On Combustion Energy And Energy Utilisation December 95.

[16]. Van Sudhakar "Performance Analysis of Adiabatic Engine" Sae 840431.

[17]. C.M.Varaprasad, K.Ram Mohan "Performance of a Diesel Engine with a Semi-Adiabatic Piston on Diesel Methanol Mixtures" Dsir Seminar on Diesel Engines, Iit, Mumbai October 88.

[18]. Rangaiaii Et Al "Performance of Ceramic Coated Diesel Engines with Methanol Diesel Mixtures" 9th National Conference in C.I Engines and Combustion 1985.

[19]. K. Ram Mohan, C.M Varaprasad. P. Ram Hohan "Performance Evaluation of Diesel Engine with A Air-Gap Insulated Piston" Annual Paper Meeting the Institution of Engineers.

[20]. Dr.HiregoudarYerrennagoudar,Manjunatha K, et.al, "Performance and Emission Characteristics of Twin Cylinder CI Engine Using Cottonseed Oil Blended With Methanol" International Organization of Science Research Community of Researcher (IOSR) IOSR Journal of Mechanical and Civil Engineering (IOSR-JMCE) e-ISSN: 2278-1684,p-ISSN: 2320-334X, Volume 12, Issue 1 Ver. I (Jan- Feb. 2015), PP 47-53 www.iosrjournals.org

[21]. Mather and Sharma "Internal Combustion Engines" 7th Edition 1996.

[22]. Dr.HiregoudarYerrennagoudar,Manjunatha K et.al "Experimental Investigation of Twin Cylinder Diesel Engine Using Linseed oil blend with Ethanol" (ICNSE-1439)" International Congress on Natural Sciences and Engineering, May 7-9, 2015, Kyoto, Japan.

[23]. Eckland, E. E.; R. L Bechtold; T. J. Timbario; and P. W. McCallum, "State-of-the-Art Report on the Use of Alcohols in Diesel Engines", SAE Paper No. 840118.

[24]. Dr.HiregoudarYerrennagoudar, Manjunatha K, et.al. "Experimental Investigation of Twin Cylinder Diesel Engine Using Diesel \&Methanol'International Journal of modern Engineering research, (IJMER) Website:www.ijmer.com (ISSN 2249 - 6645 (Online)) Volume No.4, Issue No.7, July 2014)(7)

[25]. Dr.HiregoudarYerrennagoudar,Manjunatha K, et.al "Investigation of Methanol in Twin cylinder in line 4 Stroke liquid cooled Diesel Engine" International Conference on Mechanical, Aeronautics and Production Engineering (ICMAPE),II-RIETCHN-260751467,Beijing, China 26th July 2015.

[26]. Dr.HiregoudarYerrennagoudar, Manjunatha K, et.al "Investigation of Ethanol in Common Rail Direct Injection (CRDI) Diesel Engine" International Conference on Science, technology and Management (ICSTM), Bangkok, Thailand, $2^{\text {nd }}$ August 2015.

[27]. Dr.HiregoudarYerrennagoudar, Manjunatha K, et.al "Experimental Investigation of Twin Cylinder Diesel Engine Using Methanol", International Journal of Engineering Science and innovative Technology (IJESIT), (ISSN 2319 - 5967) (Online)) Volume No.3, Issue No.4, July2014).

[28]. Dr.HiregoudarYerrennagoudar, Manjunatha K, et.al "Performance \& emission of Twin Cylinder Diesel Engine Using Diesel \& Ethanol", International Journal of modern Engineering research, (IJMER)Website: www.ijmer.com (ISSN 2249 - 6645 (Online)) Volume No.4, Issue No.7, July 2014)(16). 
[29]. Dr.HiregoudarYerrennagoudar, Manjunatha K, et.al "Performance and Emission Characteristics of CI Engine using Hippie Oil and Cotton Seed Oil Blended with Methanol”, International Journal of Recent Development in Engineering and Technology, Website: www.ijrdet.com (ISSN 2347 - 6435 (Online)) Volume No.3, Issue No.1, July 2014).

[30]. Dr.HiregoudarYerrennagoudar,Manjunatha K, et.al "Performance \& Emission of C I Engine Using Diesel \& Ethanol Blended with Jatropa Oil" in International Journal of Recent Development in Engineering and Technology (ISSN 2347 - 6435 (Online)), Volume 2, Issue 6, June 2014.

[31]. Dr.HiregoudarYerrennagoudar, Manjunatha K, et.al "Experimental Investigation of Twin Cylinder Diesel Engine Using Jatropha and Hippie Oil Blend With Ethanol'International Organization of Science Research Community of Researcher (IOSR) Journal of Mechanical and Civil Engineering (IOSR-JMCE) e-ISSN: 2278-1684,p-ISSN: 2320-334X, Volume 12, Issue 1 Ver. I (Jan- Feb. 2015), PP 54-60 www.iosrjournals.org, DOI: 10.9790/1684-12115460.

[32]. Dr.HiregoudarYerrennagoudar,Manjunatha K, et.al "Investigation And Performance Evaluation Of Honge Seed Oil Blended With Diesel Using The Twin Cylinder Diesel Engine" International Journal Of Advance Foundation And Research In Science \& Engineering (IJAFRSE), www.ijafrse.org,ISSN:2349-4794 (Online) Volume No.2, Issue No.3, August , 2015), impact factor 1.036, Science Central Value:26.54.

[33]. Dr.HiregoudarYerrennagoudar, Manjunatha K, et.al "Investigation And Performance Evaluation Of Pine oil Blended With Diesel Using The Twin Cylinder Diesel Engine” International Journal of latest technology in management and applied science, (ISSN 2278 - 2540) Volume No. IV, Issue No. IX, September, 2015) PP 01-05.

[34]. Dr.HiregoudarYerrennagoudar, Manjunatha K, et.al"Investigation of Methanol In Twin Cylinder In Line 4 Stroke Liquid Cooled Diesel Engine", International Journal of Mechanical and Production Engineering(IJMPE),Volume-3,Issue-9,Sept.-2015 PP 5560 ,2015IRAJDOINumberIJMPE-IRAJ-DOI-2909URL-http://www.iraj.in/journal/journal_file/journal_pdf/2-183-14412833485560.pdf Impact Factor : 3.05 .

[35]. Dr.HiregoudarYerrennagoudar, Manjunatha K, et.al“Investigation and Performance Evaluation of Ethanol Blended with Diesel Using the Single Cylinder Diesel Engine" Journal of International Journal of Mechanical Engineering Research (FOREX-IJMER) Volume 3, Issue 3, September 2015, http://www.forexjournal.co.in/publication.aspx.

[36]. Dr.HiregoudarYerrennagoudar, Manjunatha K, et.al“Investigation and Performance Evaluation of Rubber Seed oil Blended with Diesel Using the Twin Cylinder Diesel Engine" Journal of International Journal of Mechanical Engineering Research (FOREXIJMER) Volume 3, Issue 3, September 2015, http://www.forexjournal.co.in/publication.aspx.

[37]. Dr.HiregoudarYerrennagoudar,Manjunatha K, et.al“"Investigation and Performance Evaluation of Ethanol Blends with Vegetable Oils as Alternative Fuels in Diesel Engine Performance" International Journal on Mechanical Engineering and Robotics (IJMER), ISSN (Print) : 2321-5747, Volume-3, Issue-2,2015.

[38]. T. Le Anh,I.K. Reksowardojo,K. Wattanavichien "Handbook of Biofuels Production" Processes and Technologies,A volume in Woodhead Publishing Series in Energy,2011, Pages 611-646,23-Utilisation of biofuels in diesel engines, doi:10.1533/9780857090492.4.611, Elsevier Publisher.

[39]. Seung Hyun Yoon, Chang Sik Lee, "Effect of biofuels combustion on the nanoparticle and emission characteristics of a commonrail DI diesel engine",Fuel,Volume 90, Issue 10, October 2011, Pages 3071-3077,doi:10.1016/j.fuel.2011.05.007, Elsevier Publisher.

[40]. F.J. Salvador,J. Martínez-Lopez ,J.-V. Romero ,M.-D. Rosello "Mathematical models of addictive behaviour, medicine \& engineering, Influence of biofuels on the internal flow in diesel injector nozzles", Mathematical and Computer Modelling,Volume 54, Issues 7-8, October 2011, Pages 1699-1705,doi:10.1016/j.mcm.2010.12.010, Elsevier Publisher. 